\title{
Drug-Eluting Stents in Malignant Biliary Obstruction: Where Do We Stand?
}

\author{
Tilak Shah
}

Published online: 19 December 2012

(c) Springer Science+Business Media New York 2012

In patients with malignant biliary obstruction, endoscopic placement of biliary stents offers similar technical success rates but a lower risk of complications and a trend towards decreased mortality when compared to surgical bypass and percutaneous drainage $[1,2]$. As a result, over the last three decades, endoscopic retrograde cholangiography (ERC)guided stent placement has become the preferred approach to palliate malignant biliary obstruction.

Until the 1990s, only plastic stents were available. Plastic stents may occlude within 3-6 months, often requiring repeated ERC procedures in order to exchange the stents. The introduction of a stainless-steel uncovered metal stent (Wallstent, Boston Scientific) heralded a major advance in extending the duration of stent patency. Although self-expandable metallic stents (SEMS) are more expensive than plastic stents, they are cost-effective when compared to plastic stents for patients expected to live longer than 3 months due to the need for fewer subsequent ERC procedures [1, 3-6]. Nonetheless, SEMS do eventually occlude in 19-40\% of patients [3-5]. The duration of SEMS patency has remained largely unchanged in spite of modifications in stent composition and the addition of a plastic coating [7-9]. Thus, a clear need exists for technologic improvements that minimize stent occlusion.

The major mechanisms of SEMS occlusion are tumor ingrowth, tumor overgrowth, and epithelial hyperplasia. These mechanisms provide the rationale for developing a stent that is coated with or locally elutes a chemotherapeutic agent in order to improve stent patency. In vitro and animal studies suggest that a paclitaxel-coated stent may be

T. Shah $(\bowtie)$

Division of Gastroenterology, Duke University Medical Center,

Box 3913, Durham, NC 27710, USA

e-mail: tilak.shah@duke.edu safe and potentially efficacious when used for malignant biliary obstruction. Kalinoswki et al. [10] demonstrated that incubation with paclitaxel inhibited proliferation of human gallbladder cells, human fibroblasts, and pancreatic cells in a dose-dependent fashion. In a porcine model, SEMS coated with a paclitaxel-incorporated membrane were not associated with transmural necrosis or perforation [11]. Paclitaxel-eluting stents also appear to be safe in a canine model [12].

Limited data exist regarding outcomes of paclitaxeleluting stents for malignant biliary obstruction in humans. In a pilot study of 21 humans with malignant biliary obstruction, SEMS coated with a paclitaxel-incorporated membrane remained patent for a mean of 429 days (cumulative patency rate at 3, 6, and 12 months of 100, 71, and $36 \%$, respectively) [13]. The pilot study suggests a paclitaxel-coated SEMS may provide longer patency rates than the 10-12 months provided by standard uncovered or covered SEMS and informed the author's decision to proceed with a larger prospective study [1].

The current study by the same investigators is a prospective comparison of standard covered SEMS to SEMS covered by a paclitaxel-incorporated membrane [14]. Stents were $5-8 \mathrm{~cm}$ in length and $10 \mathrm{~mm}$ in diameter in both groups. The authors initially planned the study as a randomized controlled trial, with a calculated sample size of 36 patients in each group for the primary outcome of stent patency. Due to strong patient preference for the paclitaxelincorporated stent, the study design was modified to first consecutively enroll 60 patients to the paclitaxel-coated stent arm and then enroll 46 patients to the covered SEMS group. Mean duration of stent patency was $199 \pm 235$ days in the paclitaxel-incorporated SEMS group and $149 \pm$ 99 days in the covered SEMS group. Mean survival was $270 \pm 260$ days in the paclitaxel-incorporated SEMS 
Table 1 Summary of published human and animal studies on drug-eluting biliary stents

\begin{tabular}{|c|c|c|c|c|}
\hline Author & Journal & Subjects & Drug & Study results \\
\hline Lee & $\begin{array}{l}\text { Gastrointestinal Endoscopy } \\
2005\end{array}$ & 2 pigs & Paclitaxel & $\begin{array}{l}\text { Drug release and histologic changes best with } 10 \% \mathrm{wt} / \mathrm{v} \text { paclitaxel stent } \\
\text { compared to the } 0 \text { and } 20 \% \text { concentrations }\end{array}$ \\
\hline Suk & $\begin{array}{l}\text { Gastrointestinal Endoscopy } \\
2007\end{array}$ & 21 humans & Paclitaxel & $\begin{array}{l}\text { Mean patency } 429 \text { days } \\
\text { Mean survival } 350 \text { days }\end{array}$ \\
\hline Lee & $\begin{array}{l}\text { Gastrointestinal Endoscopy } \\
2009\end{array}$ & 11 dogs & Paclitaxel & $\begin{array}{l}\text { Mucosal hyperplasia seen in } 3 / 6 \text { dogs who received paclitaxel stent but no } \\
\text { dogs who received control stents }\end{array}$ \\
\hline Chung & $\begin{array}{l}\text { Journal of } \\
\text { Gastroenterology and } \\
\text { Hepatology } 2012\end{array}$ & 2 pigs & Gemcitabine & $\begin{array}{l}\text { No inflammation with } 0 \% \mathrm{w} / \mathrm{v} \text { gemcitabine stent } \\
\text { Mild inflammation with } 10 \% \mathrm{w} / \mathrm{v} \text { stent } \\
\text { Moderate to severe inflammation with } 15 \text { and } 20 \% \mathrm{w} / \mathrm{v} \text { stent }\end{array}$ \\
\hline Jang & Endoscopy 2012 & 8 pigs & Paclitaxel & $\begin{array}{l}\text { Paclitaxel detected in serum for } 28 \text { days using } 10 \% \text { Pluronic and } 10 \% \\
\text { paclitaxel but only } 7 \text { days with higher or lower concentrations of Pluronic }\end{array}$ \\
\hline
\end{tabular}

group and $182 \pm 117$ in the covered SEMS group. Thus, there was a trend towards improved patency and survival in the experimental arm, although these differences were not statistically significant. Rates of complications such as cholangitis, pancreatitis, and stent migration were similar between the two groups. The study therefore suggests that paclitaxel-incorporated SEMS are probably as safe as covered SEMS, but do not significantly improve stent patency or survival.

When considering the utility of drug-eluting stents for malignant biliary obstruction, several questions remain unanswered. The first question is whether the results of this study are convincing enough to conclude that the stents used in the experimental arm lack additional efficacy compared to covered stents. The non-randomized nature of the trial does create a potential for selection bias, particularly since the authors did not compare performance status or comorbidity indices between the two groups. That being said, baseline characteristics such as age and chemotherapy treatment were similar in the two groups. Also, the investigators did enroll sufficient numbers of patients to minimize type II error (erroneously rejecting the null hypothesis of no difference). Ideally, a randomized trial is necessary to confirm the results of this study. However, in light of the lack of efficacy in this study, the cost of further research using the same stent design may not be financially practical.

A second question is what effect changes in stent design may have on drug-eluting stent patency. Interestingly, tumor ingrowth and overgrowth were more common in the paclitaxel-incorporated stent group. The investigators raise the possibility of single polyurethane membrane degradation by hydrolysis, oxidation, and continuous contact with bile flow as a potential cause of tumor ingrowth in both groups. Further, they report the recent development of a double-layer drug-eluting SEMS to overcome the limitation of membrane degradation. If prior experience with plastic stents provides any guidance, it seems less likely that addition of a double-layer will confer any added benefit to drug-eluting SEMS [15].

The optimal drug, if any, to incorporate in a stent for local control of malignant biliary obstruction is not clear. The investigators used in vitro evidence from cell cultures to base their decision to incorporate the drug-eluting stent with paclitaxel, but this agent has not been effective as a systemic chemotherapeutic agent in patients with pancreatic cancer or hepatobiliary malignancies. Medications such as gemcitabine and fluorouracil are more commonly employed in patients with malignancies that frequently cause biliary obstruction. Until recently, the challenge in developing a gemcitabine-eluting stent was the hydrophilic nature of this drug, since most of the drug is eluted initially, with little left for sustained elution during the stent lifetime. The authors have recently published their pilot experience with gemcitabine-eluting SEMS in a porcine model [16]. To date, however, human experience with gemcitabine stents is lacking.

Finally, the duration a drug-eluting SEMS must continue to elute the chemotherapeutic agent for optimal efficacy is not well understood. In the current study, serum paclitaxel levels were not measured, so it is not clear how long paclitaxel exerted its anti-tumor effect, if any. The investigators have recently published their experience with a paclitaxel eluting stent that contains a Pluronic F-127 impregnated membrane in pigs [17]. Paclitaxel was detected in porcine serum for 28 days when they used SEMS covered with this surfactant-impregnated membrane containing $10 \%$ paclitaxel. Again, published human experience with this stent design is pending.

Current available evidence suggests that the first generation paclitaxel incorporated SEMS are probably safe, but are no more efficacious than standard covered SEMS (Table 1). Further investigation is necessary to determine if changes in stent design, chemotherapeutic agent, or drugrelease mechanisms will provide any added improvement to stent patency or patient survival. 
Conflict of interest None.

\section{References}

1. Moss AC, Morris E, Mathuna P. Palliative biliary stents for obstructing pancreatic carcinoma. Cochrane Database Syst Rev. 2006;2:CD004200.

2. Speer AG, Cotton PB, Russell RC, et al. Randomised trial of endoscopic versus percutaneous stent insertion in malignant obstructive jaundice. Lancet. 1987;2:57-62.

3. Davids PH, Groen AK, Rauws EA, Tytgat GN, Huibregtse K. Randomised trial of self-expanding metal stents versus polyethylene stents for distal malignant biliary obstruction. Lancet. 1992; 340:1488-1492.

4. Kaassis M, Boyer J, Dumas R, et al. Plastic or metal stents for malignant stricture of the common bile duct? Results of a randomized prospective study. Gastrointest Endosc. 2003;57:178-182.

5. Knyrim K, Wagner HJ, Pausch J, Vakil N. A prospective, randomized, controlled trial of metal stents for malignant obstruction of the common bile duct. Endoscopy. 1993;25:207-212.

6. Moss AC, Morris E, Leyden J, MacMathuna P. Do the benefits of metal stents justify the costs? A systematic review and metaanalysis of trials comparing endoscopic stents for malignant biliary obstruction. Eur J Gastroenterol Hepatol. 2007;19:1119-1124.

7. Ahmad J, Siqueira E, Martin J, Slivka A. Effectiveness of the Ultraflex Diamond stent for the palliation of malignant biliary obstruction. Endoscopy. 2002;34:793-796.

8. Dumonceau JM, Cremer M, Auroux J, Delhaye M, Devière J. A comparison of Ultraflex Diamond stents and Wallstents for palliation of distal malignant biliary strictures. Am J Gastroenterol. 2000;95:670-676.
9. Ferlitsch A, Oesterreicher C, Dumonceau JM, et al. Diamond stents for palliation of malignant bile duct obstruction: a prospective multicenter evaluation. Endoscopy. 2001;33:645-650.

10. Kalinowski M, Alfke H, Kleb B, Dürfeld F, Joachim Wagner H. Paclitaxel inhibits proliferation of cell lines responsible for metal stent obstruction: possible topical application in malignant bile duct obstructions. Invest Radiol. 2002;37:399-404.

11. Lee DK, Kim HS, Kim KS, et al. The effect on porcine bile duct of a metallic stent covered with a paclitaxel-incorporated membrane. Gastrointest Endosc. 2005;61:296-301.

12. Lee SS, Shin JH, Han JM, et al. Histologic influence of paclitaxel-eluting covered metallic stents in a canine biliary model. Gastrointest Endosc. 2009;69:1140-1147.

13. Suk KT, Kim JW, Kim HS, et al. Human application of a metallic stent covered with a paclitaxel-incorporated membrane for malignant biliary obstruction: multicenter pilot study. Gastrointest Endosc. 2007;66:798-803.

14. Jang SI, Kim J-H, You JW, et al. Efficacy of a metallic stent covered with a paclitaxel-incorporated membrane versus a covered metal stent for malignant biliary obstruction: a prospective comparative study. Dig Dis Sci. 2012. doi:10.1007/s10620-0122472-1.

15. Katsinelos P, Paroutoglou G, Chatzimavroudis G, et al. Prospective randomized study comparing double layer and Tannenbaum stents in distal malignant biliary stenosis. Acta Gastroenterol Belg. 2010;73:445-450.

16. Chung MJ, Kim H, Kim KS, Park S, Chung JB, Park SW. Safety evaluation of self-expanding metallic biliary stents eluting gemcitabine in a porcine model. J Gastroenterol Hepatol. 2012;27:261-267.

17. Jang SI, Kim JH, Kim M, et al. Porcine feasibility and safety study of a new paclitaxel-eluting biliary stent with a Pluroniccontaining membrane. Endoscopy. 2012;44:825-831. 